QIJEI

International

Journal for

Educational

Integrity

\title{
Determining the opinions of health sciences students and faculty regarding academic integrity
}

\author{
Ken Randall, PT, MHR \\ College of Allied Health \\ The University of Oklahoma Schusterman Center \\ Denise G Bender, PT, GCS, Med, JD \\ College of Allied Health \\ The University of Oklahoma Schusterman Center
}

Diane M Montgomery, PhD

School of Applied Health and Educational Psychology

Oklahoma State University

Keywords: academic integrity, Q method, health sciences education, occupational therapy, physical therapy

\begin{abstract}
This study used $Q$ method to understand the opinions of students and faculty in health sciences programs in physical therapy and occupational therapy regarding what they consider to be key aspects of academic integrity, viewing it from the perspectives of the individual, the academic program, practitioners, and society. Thirty-eight students and faculty sorted statements on academic integrity to represent their reactions to the condition of instruction, "What are your thoughts about values in your academic program?" Data were analysed by correlating the sorts and using factor analysis and rotation to produce two factors, each with distinct views of academic integrity. 'Collective Integrity' reflects a more society-oriented view and 'Personal Integrity' shows a more internally-driven view. Demographic information revealed that more students, women, and those less than thirty years of age define the Collective Integrity factor, which is substantiated through theoretical interpretation using Gilligan's feminist theory of development. Demographics of academic role, age, and gender were not as strongly linked to the Personal Integrity factor. The implications of this study include the need for academic institutions to develop or continue with established policies that promote academic integrity, and for further research on this subject, as well as that of academic dishonesty.
\end{abstract}

\section{Background and purpose}

Academic integrity is a topic of great interest among educational institutions around the world (Center for Academic Integrity, 2007; McCabe, Trevino, \& Butterfield, 2001; Turner \& Beemsterboer, 2003). The generally accepted definition of academic integrity is "honesty in all manners relating to endeavors of the academic environment" (Turner \& Beemsterboer, 2003, p. 1122). The converse of this concept is academic dishonesty, which includes behaviours such as cheating on examinations, plagiarism, or generally diminished effort (Niels, 1996). Recently, students and faculty in our academic program identified issues of academic dishonesty among a small subset of students, which triggered in-depth conversations about academic integrity. These discussions, informed by a review of the literature on

The International Journal for Educational Integrity is available online at:

http://www.ojs.unisa.edu.au/journals/index.php/lJEI/

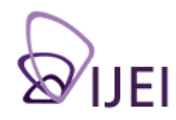


the subject, led to this study of the opinions and perceptions of students and faculty regarding academic integrity.

The growing perception that academic dishonesty is at "epidemic levels" (Hall \& Kuh, 1998, p. 2) is supported by its pervasiveness in colleges and universities worldwide. The prevalence rate for academic dishonesty in Australia is estimated at $23 \%$ or higher (Brimble \& Stevenson-Clarke, 2005), 64\% in Russia, 55\% in the United States (Lupton \& Chapman, 2000), and 61.72\% in Taiwan (Lin \& Wen, 2007). Specific breaches of academic integrity are varied. Among them are cheating on examinations (including copying the answers of another and providing answers after a test), writing papers for another student, giving prohibited help on an assignment, and submitting someone else's work as your own (Diekhoff et al., 1996; Lin \& Wen, 2007; Turner \& Beemsterboer, 2003). One of the most common forms of academic dishonesty is plagiarism: direct copying or near copying from a source without referencing (Turner \& Beemsterboer, 2003). The estimated prevalence of plagiarism is between 30 and $46 \%$ in Australia (Sharman \& Wilshire, 2007), between 25 and 50\% in the United Kingdom (Kilner, 2004; Szabo \& Underwood, 2004) between 70 to 85\% in the United States (Tyre, 2001), and 66\% in Taiwan (Lin \& Wen, 2007).

Studies related to academic integrity specific to health care education are found in nursing, pharmacy, dentistry, medicine, and health sciences programs including physical therapy and occupational therapy. Gaberson (1997) provided a useful overview of the effects of academic dishonesty in nursing education, and related its negative influence on patient care, the academic program, and society's view of the profession. Rabi, Patton, Fjortoft and Zgarrick (2006) identified cheating behaviours among pharmacy students and offered evidence that cheating in the classroom extends to clinical practice. Editorials by Lingen (2006) and Glick (2001) expressed the efforts of faculty and students in dentistry and medicine to comprehend the cheating behaviours of some students and the struggle of what to do about it. A study particular to allied health education raised the question of whether students and faculty have different views of academic dishonesty (Falleur, 1990). In general, the issues related to academic integrity in health care education are similar to those in other academic arenas; however, they have the added dimension of clinical practice. Consensus among authors is that gaining a better understanding of what students and faculty think about academic integrity is an important element of developing steps to address the issue.

Hall and Kuh (1998) suggested that one can better understand academic integrity and related behaviours by viewing it through a "cultural lens," which contains various perspectives (p. 3). We developed such a lens to better comprehend and represent the scope of viewpoints pertaining to academic integrity as it relates to our health sciences programs in physical therapy and occupational therapy. A review of the literature informed the development of our theoretical framework of twenty such views, consisting of four perspectives linked with five behaviours that define academic integrity. The four groups that hold perspectives on academic integrity in health related academic programs are those of the individual (either a student or a faculty member), the academic program as a whole (McCabe, Trevino, \& Butterfield 2002), clinical practitioners, and society in general (Davis, Johnston, DiMicco, Findlay, \& Taylor, 1996; Gabbay, 1999). Each of the four viewpoints may focus on any of five behaviours that define academic integrity, as established by the 320-plus academic institutions worldwide that constitute the Center for Academic Integrity: honesty, trust, fairness, respect and responsibility (Center for Academic Integrity, 1999). Combining these four perspectives with the five behaviours associated with academic integrity produced our theoretical framework matrix, or cultural lens of twenty potential viewpoints on academic integrity, each producing a particular opinion related to academic integrity. This theoretical framework (see Table 1) served as our guide to describe the views of occupational therapy and physical therapy students and faculty regarding what they considered to be key components related to academic integrity. 


\section{Table 1}

A theoretical lens for viewing academic integrity in health education programs, consisting of four perspectives on five behaviors, producing a framework of twenty potential viewpoints (with a description of each point of view provided).

Given the growing concern of both students and faculty about academic integrity in our professional programs, we believed it was important to understand their viewpoints on the matter. We were particularly interested in whether students and faculty shared particular opinions or if their views were in opposition to each other. We also wondered if characteristics such as gender, age, and professional discipline were related to specific viewpoints. Q method is well suited for this task because it seeks to

\begin{tabular}{|l|l|l|l|l|l|}
\hline & Honesty & Trust & Fairness & Respect & Responsibility \\
\hline $\begin{array}{l}\text { Personal } \\
\text { perspectives } \\
\text { (student or } \\
\text { faculty } \\
\text { member) }\end{array}$ & $\begin{array}{l}\text { Personal } \\
\text { values and } \\
\text { beliefs }\end{array}$ & $\begin{array}{l}\text { Relationships } \\
\text { with others }\end{array}$ & $\begin{array}{l}\text { Taking care } \\
\text { of self }\end{array}$ & $\begin{array}{l}\text { Focus on } \\
\text { others over self } \\
\text { Bedside } \\
\text { manner }\end{array}$ & $\begin{array}{l}\text { Self- } \\
\text { monitoring }\end{array}$ \\
\hline $\begin{array}{l}\text { Academic } \\
\text { program } \\
\text { perspectives }\end{array}$ & $\begin{array}{l}\text { Cheating } \\
\text { and } \\
\text { plagiarism }\end{array}$ & $\begin{array}{l}\text { Proctoring } \\
\text { examinations, } \\
\text { checking for } \\
\text { plagiarism }\end{array}$ & $\begin{array}{l}\text { Everyone } \\
\text { treated } \\
\text { equally }\end{array}$ & $\begin{array}{l}\text { Professional- } \\
\text { ism and } \\
\text { diversity }\end{array}$ & $\begin{array}{l}\text { Gate keepers } \\
\text { of the } \\
\text { profession }\end{array}$ \\
\hline $\begin{array}{l}\text { Clinical } \\
\text { perspectives }\end{array}$ & $\begin{array}{l}\text { Codes of } \\
\text { ethics }\end{array}$ & $\begin{array}{l}\text { Patient- } \\
\text { practitioner } \\
\text { confidentiality }\end{array}$ & $\begin{array}{l}\text { We are } \\
\text { ethically } \\
\text { bound to treat }\end{array}$ & $\begin{array}{l}\text { Patient } \\
\text { centeredness } \\
\text { and rapport }\end{array}$ & \begin{tabular}{l} 
"Do no harm." \\
\hline $\begin{array}{l}\text { Societal } \\
\text { perspectives }\end{array}$
\end{tabular} \\
$\begin{array}{l}\text { "So help } \\
\text { me God." }\end{array}$ & $\begin{array}{l}\text { Contract with } \\
\text { society }\end{array}$ & $\begin{array}{l}\text { Do unto } \\
\text { others }\end{array}$ & $\begin{array}{l}\text { All people are } \\
\text { created equally }\end{array}$ & $\begin{array}{l}\text { Taking care } \\
\text { of fellow } \\
\text { human } \\
\text { beings }\end{array}$ \\
\hline
\end{tabular}

understand opinions and it takes advantage of the strengths of both qualitative and quantitative research (Cross, 2005). Further, no Q study has been performed on this topic to enlighten us on the views of students and faculty in regard to academic integrity.

\section{Method}

Q method is a research tool used to study human subjectivity (Brown, 1993; Stephenson, 1953). William Stephenson, a physicist and psychologist who created $Q$ in the early 1930s, emphasised that $Q$ is interested in understanding more than explaining, and it strives to determine how things work as opposed to why (Smith, 2001 , p. 323). It combines both quantitative and qualitative research approaches to provide a systematic means for examining the opinions, preferences, and perspectives of individuals (McKeown \& Thomas, 1988). Q method uses quantitative research methods to efficiently and meaningfully summarise large amounts of data, and it also employs qualitative research methods, which allows for theoretical interpretation of the data (Barata, 2007). In overview, Q method consists of the following steps: establishing a sample of opinion statements about a topic of interest; having participants in the study perform a "Q-sort" in which they execute a ranking of the statements as more-like or less-like their own perspectives; development of a correlation matrix based on the rankings to create groupings of individuals with similar views; and qualitative interpretation of the groupings, seeking to describe the subjective views of each group and how they compare to other groups. For this study, a purposive sample of thirty-eight occupational therapy and physical therapy students 
and faculty at an urban university-affiliated health sciences centre in the mid-western United States was solicited to ascertain their opinions about academic integrity. This sample, or 'P-set', (Brown, 1993) consisted of thirty-three students and five faculty members ranging in age from twenty-one to sixty-one years, of which thirty were associated with the physical therapy program and eight with occupational therapy. The gender distribution was six males and thirty-two females. The volunteers who agreed to participate signed the informed consent document and took part in the study.

The $Q$ method process for our study began by formulating a sample of statements, also known as the "Q-set," from a larger group, called the "concourse," which reflects the totality of perspectives on academic integrity (Smith, 2001, p. 323). Each statement serves as a point of self-reference, such that participants identify with its viewpoint, feel neutral about it, or believe that the statement is less like their personal perspectives (Smith, 2001, p. 324). We used our theoretical framework of twenty perspectives to generate the diversity of viewpoints on academic integrity. We accessed a variety of resources to develop our concourse sample, which included journal articles, editorials and commentaries, Internet sites, and personal web logs. Our resources reflected the spectrum of opinions on academic integrity, ranging from international groups such as the Center for Academic Integrity to individuals whose sole purpose was to help others to 'beat the system' using the latest methods of cheating or by selling term papers on virtually any topic.

After gathering over 300 opinion statements that were for, against, or neutral on the subject of academic integrity, we selected thirty-six statements to serve as our sample of the concourse. Cross (2005) suggests that a Q-set can consist of anywhere between ten and 100 statements. Choosing thirty-six statements allowed us to include at least one statement (and in most cases two) for each of the twenty perspectives of our theoretical lens, without the sorting process becoming unwieldy. We numbered each statement to reflect its position on the theoretical framework matrix. An example of a statement from our Q-set is the viewpoint that "We become morally bound to help, by virtue of the promise that comes with the responsibility of professionalism: that we will be there, that we will care, and that, above all, we will do no harm" (Davis, 1989 , p. 40). This particular statement represents the clinical perspective on responsibility found in our theoretical framework. In addition to containing statements such as this that are related to academic integrity, the Q-set also contained statements that pertained to the various aspects of academic dishonesty, including cheating on exams, plagiarism, and giving prohibited help. One such example is the statement reflecting the personal perspective on honesty (and directly linked to plagiarism), "It's okay to use the exact words of another in my paper without referencing; I knew what I wanted to say, they just said it better."

Participants then performed a Q-sort of the sample statements, placing them on a 'form board', that contained the same number of cells as statements. The form board is an important aspect of $Q$ method because it assists the participants in ranking the statements along a continuum, placing them in columns from 'most like' to 'most unlike' their point of view. Table 2 depicts the form board that we used in our study. Each column has a specific number of cells, which are typically arranged to produce a bell-shaped distribution (Cross, 2005; McKeown \& Thomas, 1988). Each column is rank ordered, and in the case of the form board that we selected, they ranged numerically from -4 (most unlike) to +4 (most like). To perform the Q-sort, participants received an envelope that contained the thirty-six statements, each of which was printed on an individual piece of paper that was the same size as an individual cell on the form board. Participants were instructed to read all of the statements and to place them in columns on the form board according to whether they were 'most like' or 'most unlike' their own viewpoints. The condition of instruction that we used was, "What are your thoughts about values in your academic program?" Participants could place only one statement in each cell on the form board. In some instances, this 
produced a forced choice in which participants had to decide into which column to place a statement, thus ranking to what degree that statement was like or unlike the participant's point of view. Statements that were placed in the central portion of the form board reflected more neutral opinions for the participant.

\section{Table 2}

The thirty-six item form board used for this $Q$ study produces a normal distribution for sorting statements

As the participants sorted, they had the opportunity to move individual statements from one column to another until they were satisfied with the placement of each statement within a particular column. The first participant finished the sort in twenty minutes, and the last participant finished in fifty minutes. Once completed, the participants transferred the number of each statement onto a report form that contained a table identical to the form board and then completed a short demographic

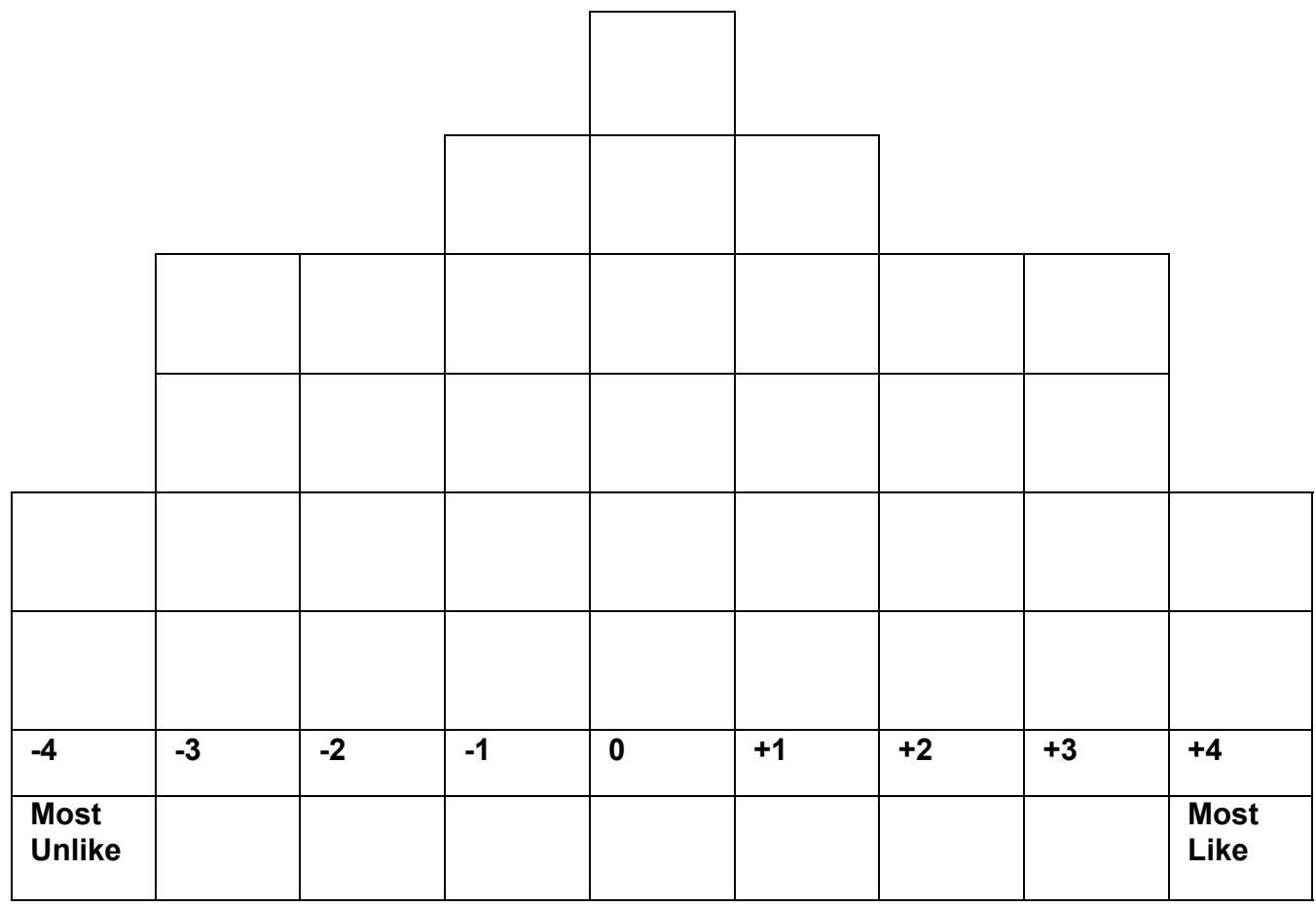

survey that captured information about the participant's professional program, gender, and age. The survey included space for the participant to respond to the question, "What would you like to say about academic integrity in your program?" and provided participants with the option to consent to a possible follow-up telephone interview, if clarification on understanding a factor was needed. Those willing to be a part of a follow-up interview provided their first name and a telephone number on the survey form. In this study, follow-up phone calls were made to five sorters to assist in the interpretation of the factors.

Using the numbering of the statements on the form board to reflect placement of each statement within the distribution, we computed a correlation matrix to determine particular factors or groupings of related sorts (Schmolck \& Atkinson, 2002). Statements were then ordered from calculated $z$-scores to represent a theoretical typal array. In our study, data were analysed using PQMethod 2.11, a statistical program customised for $Q$ studies and available from www.qmethod.org (Schmolck \& Atkinson, 2002). The software computed inter-correlations and factor analysed the correlations, followed by rotation and the computation of a z-score for each statement for each factor. We used Centroid factor analysis with Varimax analytical rotation to determine particular factors or statistically significant groupings of opinions. Analyses 
using between three and seven centroids all produced three factors, the third of which contained only two sorts and produced a large number of confounded significant loadings among the other sorts (that is, one sort achieved significance on more than one factor). For this reason, we chose to rotate only two factors, resulting in only three confounded sorts with thirty-five of the thirty-eight sorts defining either of the two factors (see Table 3). The remaining three sorts were 'split' between the two factors, and were hand-eliminated from the factor definition. The consequent two factors explained $68 \%$ of the total variance, with twenty-one sorts defining factor one and fourteen sorts defining factor two.

\section{Table 3}

Factor matrix of $Q$ sorts, with ' $X$ ' indicating a defining sort and '*' reflecting a sort that is split between the two factors

\begin{tabular}{|c|c|c|}
\hline QSORT & Factor 1 & Factor 2 \\
\hline 1 FOTM51 & 0.4715 & $0.5657 X$ \\
\hline 2 FPTF37 & 0.4323 & $0.6842 X$ \\
\hline 3 SPTF26 & $0.8195 X$ & 0.3814 \\
\hline 4 SOTF46 & 0.5164 & $0.5374 X$ \\
\hline 5 SPTF21 & 0.5176 & $0.6521 X$ \\
\hline 6 SPTF21 & $0.7246 X$ & 0.5760 \\
\hline 7 SOTF41 & $0.4998 X$ & 0.4699 \\
\hline 8 SPTF21 & 0.5916 & $0.6239 X$ \\
\hline 9 SOTM21 & $0.7009 X$ & 0.5333 \\
\hline 10 SPTF21 & $0.7210 x$ & 0.3684 \\
\hline 11 SPTF21* & 0.5791 & 0.5826 \\
\hline 12 SPTF26 & $0.7906 X$ & 0.3690 \\
\hline 13 SPTF21 & $0.6699 X$ & 0.4362 \\
\hline 14 SPTF21 & $0.8108 X$ & 0.3196 \\
\hline 15 SPTM26 & $0.7028 X$ & 0.4872 \\
\hline 16 SPTM37 & 0.2611 & $0.7150 X$ \\
\hline 17 SPTF37 & 0.3540 & $0.7787 X$ \\
\hline 18 SPTF21 & $0.7886 X$ & 0.4578 \\
\hline 19 SOTN21 & 0.2741 & $0.5019 X$ \\
\hline 20 SPTF21* & 0.5823 & 0.5762 \\
\hline 21 SPTF21 & 0.2783 & $0.6382 X$ \\
\hline 22 SOTF21 & $0.6665 X$ & 0.4872 \\
\hline 23 SPTF21 & 0.5827 & $0.6240 X$ \\
\hline 24 SPTF26 & $0.6701 X$ & 0.3321 \\
\hline 25 SPTF37 & $0.6354 X$ & 0.5196 \\
\hline 26 SPTF21 & 0.5739 & $0.6584 X$ \\
\hline 27 FPTF61* & 0.5592 & 0.5468 \\
\hline 28 SPTF21 & $0.6335 X$ & 0.5280 \\
\hline 29 SPTM21 & $0.6367 X$ & 0.1992 \\
\hline 30 FPTF41 & 0.3957 & $0.7399 X$ \\
\hline 31 SOTF21 & $0.6344 X$ & 0.4761 \\
\hline 32 SPTM21 & $0.6125 X$ & 0.4767 \\
\hline 33 SPTF21 & $0.6014 X$ & 0.5951 \\
\hline 34 SPTF41 & $0.7322 x$ & 0.5464 \\
\hline 35 SPTF21 & 0.5755 & $0.6824 X$ \\
\hline 36 SPTF21 & $0.7839 X$ & 0.3528 \\
\hline 37 FOTF46 & $0.6524 X$ & 0.5730 \\
\hline 38 SPTF21 & 0.2848 & $0.8472 x$ \\
\hline Total Definin & 21 & 14 \\
\hline
\end{tabular}

The final step in $Q$ method is to interpret the typal arrays and the related statements, seeking to describe the subjective views of the defining sorts in each group and how they compare to the typal arrays or defining sorts of participants in the other factors or groupings. Our data analysis produced two particular factors or groupings. We present these two factors and our interpretation of the groupings in the following two sections. 


\section{Results}

Examination of the z-scores for the two factors revealed a large number of consensus statements (twenty-seven of the thirty-six items). This reflects similarly held opinions on academic integrity between the groups of people who sorted these statements. Of note is consensus among all participants that they were 'most unlike' those statements in support of academic dishonesty, such as "I feel very good about myself when I cheat and get away with it... cheating is an art form that I improve upon." Participants in the study shared neutrality on perspectives such as "Laxity about cheating in school will ultimately weaken the fabric of our society," and "Equality, justice, and social change all have their roots in our perceptions of fairness." The participants agreed on some, but not all, opinions that they perceived as being more like their own. For instance, the statement that all participants agreed upon as being 'most like' them reflected the 'golden rule', of 'treat others the same way you want them to treat you'. Although the participants in the study were in agreement on many opinions, it is the analysis of those statements that distinguishes each of the two factors that led us to understand their differing viewpoints and assisted us in naming each factor according to its unique perspective.

Factor one: Collective Integrity. The twenty-one participants whose sorts defined this factor, view honesty and moral responsibility as part of their motivation in making academic decisions (see Table 4). Critical statements for this factor were, "I believe in being honest, true, virtuous, and in doing good to all people," and "Moral responsibility is to accept what is required, to honour the role that has been entrusted, and to perform to the best of one's ability." Further, this perspective extends integrity to an interpersonal and global manner of human interaction, as reflected by one of the statements that defined this factor, "My goal is to help create a world where all people are treated with fairness, decency, and respect." Given this viewpoint that is oriented toward society and the good of the whole, we named this factor "Collective Integrity". Follow-up interviews with those participants who consented to an interview whose sorts were closely associated with the theoretical view substantiated this conclusion. Participant \#12, who had a loading of 0.79 for this factor reflected this orientation toward others: "I love to see people happy especially when I have a hand in it." Further, this participant reflected that, "I have a responsibility to honour the position and commitments I have made in life. Personally I am not satisfied with myself if I do not perform to my best ability in something I consider important." Finally, Participant \#15 summarised the character of this factor when he said, "Society has certain expectations that we should live up to or maybe even exceed." When viewing the statements that participants in this factor perceived as 'most unlike' their own, the view, "I am my highest priority... above everyone else," is noteworthy. This statement reflects the antithesis of the collective integrity perspective, and is not surprising that participants would give it the highest ranking $(-4)$ as least like their views.

\section{Table 4}

Defining Statements for Factor One, "Collective Integrity" 
Factor Two: Personal Integrity. Fourteen participants shared views that defined this factor (see Table 5) representing a highly internal sense of values and selfmodulation. Their highest ranked statement was, "Honour means having the courage

\begin{tabular}{|c|c|c|c|c|c|}
\hline & $\begin{array}{l}\text { 23. It's } \\
\text { definitely what } \\
\text { you get } \\
\text { assigned - and } \\
\text { how long you } \\
\text { have to do it - } \\
\text { that determines } \\
\text { whether you're } \\
\text { going to cheat. }\end{array}$ & & $\begin{array}{l}34 . \text { We hold } \\
\text { these truths to } \\
\text { be self-evident, } \\
\text { that all people } \\
\text { are created } \\
\text { equal. }\end{array}$ & $\begin{array}{l}36 . \text { Moral } \\
\text { responsibility } \\
\text { is to accept } \\
\text { what is } \\
\text { required }\end{array}$ & \\
\hline & $\begin{array}{l}\text { 13. Who cares } \\
\text { about making } \\
\text { good grades? } \\
\text { "C's get } \\
\text { degrees." }\end{array}$ & & $\begin{array}{l}\text { 26. As a child, } \\
\text { did my parents } \\
\text { make a list of } \\
\text { things to tell me } \\
\text { how to conduct } \\
\text { my life? No. } \\
\text { Instead, they } \\
\text { modelled for } \\
\text { me how I } \\
\text { should live as } \\
\text { an adult. }\end{array}$ & $\begin{array}{l}27 . \text { Honour } \\
\text { means having } \\
\text { the courage } \\
\text { to make } \\
\text { difficult } \\
\text { choices \& } \\
\text { accepting } \\
\text { responsibility } \\
\text { for actions \& } \\
\text { their } \\
\text { consequences }\end{array}$ & \\
\hline $\begin{array}{l}25 . \text { I am my } \\
\text { highest } \\
\text { priority... } \\
\text { above } \\
\text { everyone else. }\end{array}$ & $\begin{array}{l}\text { 11. Teachers } \\
\text { and students } \\
\text { don't respect } \\
\text { each other... it } \\
\text { is a naturally } \\
\text { oppositional } \\
\text { relationship. }\end{array}$ & & $\begin{array}{l}\text { 17. My goal is } \\
\text { to help create a } \\
\text { world where all } \\
\text { people are } \\
\text { treated with } \\
\text { fairness, } \\
\text { decency, and } \\
\text { respect. }\end{array}$ & $\begin{array}{l}21 . \text { We are } \\
\text { bound to help }\end{array}$ & $\begin{array}{l}\text { 33. Treat others } \\
\text { the same way } \\
\text { you want them } \\
\text { to treat you. }\end{array}$ \\
\hline $\begin{array}{l}\text { 22. I feel very } \\
\text { good about } \\
\text { myself when I } \\
\text { cheat and get } \\
\text { away with it... } \\
\text { it's an art form } \\
\text { that I improve } \\
\text { upon. }\end{array}$ & $\begin{array}{l}\text { 1. Most of the } \\
\text { time, the stuff } \\
\text { you study is } \\
\text { useless in later } \\
\text { life, so if you } \\
\text { can get by } \\
\text { without } \\
\text { memorising it, } \\
\text { why not? }\end{array}$ & & $\begin{array}{l}\text { 16. Patients are } \\
\text { morally entitled } \\
\text { to protection } \\
\text { from } \\
\text { exploitation of } \\
\text { their } \\
\text { vulnerability by } \\
\text { the therapist. }\end{array}$ & $\begin{array}{l}18 . \text { We } \\
\text { should treat } \\
\text { every } \\
\text { individual with } \\
\text { respect: as } \\
\text { someone who } \\
\text { has } \\
\text { aspirations }\end{array}$ & $\begin{array}{l}29 . \text { I believe in } \\
\text { being honest, } \\
\text { true, virtuous, } \\
\text { and in doing } \\
\text { good to all } \\
\text { people... }\end{array}$ \\
\hline \multirow[t]{2}{*}{-4} & \multirow[t]{2}{*}{-3} & \multirow{2}{*}{$\begin{array}{c}\text { Columns - } \\
2,-1,0 \text {, and } \\
+1 \text { omitted }\end{array}$} & +2 & +3 & +4 \\
\hline & & & & & "Most Like" \\
\hline
\end{tabular}

to make difficult choices and accepting responsibility for actions and their consequences, even at personal cost." A second statement that they ranked as "most like' their viewpoints was, "Who are you when no one is looking?" Participants with high loadings on this factor reflect the importance of self-regulation and, as Participant \#1 said, "At the end of the day, I have to live with myself." This comment was echoed in the words of Participant \#2 who said, "You have to be true to your self." When asked in a subsequent interview how she came to believe this way, the latter participant stated, "I didn't always believe that way... I believe it's about maturity and experience... when I was younger, I think I was more concerned about what others thought, but somewhere along the way that changed." When examining the statements ranked as 'most unlike' their own, the participants who defined factor two shared a number of views with those in factor one. One statement that the individuals in this factor ranked as less like them (-3) that differed from those in the first factor was, "There are some people who I can't treat because of who they are... and if I feel that way, they are better off having someone else work with them." This view is counter to the internal regulation that defines factor two, and is not a surprise that participants would rank it as more unlike their views. 
Table 5

Defining statements for Factor Two, "Personal Integrity"

Demographic information, reflected in Table 6, provides additional insight into this study. Most of the students who sorted (twenty of thirty-one) defined Collective Integrity and most of the faculty who sorted (three of four) defined Personal Integrity. Professional role (physical therapy or occupational therapy) did not have any

\begin{tabular}{|c|c|c|c|c|c|}
\hline & $\begin{array}{l}\text { 19. There are } \\
\text { some patients } \\
\text { who I can't treat } \\
\text { because of who } \\
\text { they are... and } \\
\text { if I feel that way, } \\
\text { they're better } \\
\text { off having } \\
\text { someone else } \\
\text { work with them. }\end{array}$ & & $\begin{array}{l}\text { 30. To be } \\
\text { honest to one's } \\
\text { real self and to } \\
\text { the purpose of } \\
\text { a task earns } \\
\text { trust and } \\
\text { inspires faith in } \\
\text { others. }\end{array}$ & $\begin{array}{l}\text { 18. We } \\
\text { should treat } \\
\text { every } \\
\text { individual with } \\
\text { respect: as } \\
\text { someone who } \\
\text { has } \\
\text { aspirations, } \\
\text { needs, and, } \\
\text { most } \\
\text { important: } \\
\text { potential }\end{array}$ & \\
\hline & $\begin{array}{l}\text { 13. Who cares } \\
\text { about making } \\
\text { good grades? } \\
\text { "C's get } \\
\text { degrees." }\end{array}$ & & $\begin{array}{l}29 . \text { I believe in } \\
\text { being honest, } \\
\text { true, virtuous, } \\
\text { and in doing } \\
\text { good to all } \\
\text { people... }\end{array}$ & $\begin{array}{l}28 . \text { Who are } \\
\text { you when no } \\
\text { one is } \\
\text { looking? }\end{array}$ & \\
\hline $\begin{array}{l}\text { 23. It's } \\
\text { definitely what } \\
\text { you get } \\
\text { assigned - and } \\
\text { how long you } \\
\text { have to do it - } \\
\text { that } \\
\text { determines } \\
\text { whether you're } \\
\text { going to cheat. }\end{array}$ & $\begin{array}{l}\text { 11. Teachers } \\
\text { and students } \\
\text { don't respect } \\
\text { each other... it } \\
\text { is a naturally } \\
\text { oppositional } \\
\text { relationship. }\end{array}$ & & $\begin{array}{l}\text { 10. When a } \\
\text { school has } \\
\text { respect as the } \\
\text { cornerstone of } \\
\text { the way that } \\
\text { teachers and } \\
\text { students work } \\
\text { together; } \\
\text { students benefit } \\
\text { and learn. }\end{array}$ & $\begin{array}{l}\text { 21. We are } \\
\text { bound to } \\
\text { help, by the } \\
\text { promise that } \\
\text { comes with } \\
\text { the } \\
\text { responsibility } \\
\text { of } \\
\text { professionalism } \\
\text { : that we will } \\
\text { care, and, } \\
\text { above all, we } \\
\text { will do no } \\
\text { harm. }\end{array}$ & $\begin{array}{l}\text { 27. Honour } \\
\text { means having } \\
\text { the courage to } \\
\text { make difficult } \\
\text { choices \& } \\
\text { accepting } \\
\text { responsibility } \\
\text { for actions \& } \\
\text { their } \\
\text { consequences, } \\
\text { even at } \\
\text { personal cost. }\end{array}$ \\
\hline $\begin{array}{l}\text { 22. I feel very } \\
\text { good about } \\
\text { myself when I } \\
\text { cheat and get } \\
\text { away with it... } \\
\text { it's an art form } \\
\text { that I improve } \\
\text { upon. }\end{array}$ & $\begin{array}{l}\text { 1. Most of the } \\
\text { time, the stuff } \\
\text { you study is } \\
\text { useless in later } \\
\text { life, so if you } \\
\text { can get by } \\
\text { without } \\
\text { memorising it, } \\
\text { why not? }\end{array}$ & & $\begin{array}{l}\text { 4. You are } \\
\text { guilty of } \\
\text { cheating } \\
\text { whenever you } \\
\text { present as your } \\
\text { own work } \\
\text { something that } \\
\text { you didn't do, or } \\
\text { if you help } \\
\text { someone else } \\
\text { cheat. }\end{array}$ & $\begin{array}{l}\text { 16. Patients } \\
\text { are morally } \\
\text { entitled to } \\
\text { protection } \\
\text { from } \\
\text { exploitation of } \\
\text { their } \\
\text { vulnerability } \\
\text { by the } \\
\text { therapist. }\end{array}$ & $\begin{array}{l}\text { 33. Treat others } \\
\text { the same way } \\
\text { you want them } \\
\text { to treat you. }\end{array}$ \\
\hline \multirow[t]{2}{*}{-4} & -3 & \multirow[t]{2}{*}{$\begin{array}{l}\text { Columns - } \\
2,-1,0 \text {, and } \\
+1 \text { omitted }\end{array}$} & +2 & +3 & +4 \\
\hline & & & & & "Most Like" \\
\hline
\end{tabular}

representation for a particular factor. Although males were somewhat more evenly distributed between the two views, more females (twenty of twenty-nine) had views associated with Collective Integrity. Younger participants tended to be associated with Collective Integrity, with no clear age differentiation for Personal Integrity.

Table 6

Demographic Information for Factors 
The demographic survey also contained space for a short response to the question, "What would you like to say about academic integrity in your program?" Of the twentyone participants who responded to this question, thirteen indicated that they believed

\begin{tabular}{|l|c|c|}
\hline & $\begin{array}{c}\text { Factor One } \\
\text { Collective Integrity }\end{array}$ & $\begin{array}{c}\text { Factor Two } \\
\text { Personal Integrity }\end{array}$ \\
\hline Faculty & 1 & 3 \\
\hline Student & 20 & 11 \\
\hline PT & 16 & 11 \\
\hline OT & 5 & 3 \\
\hline Male & 4 & 2 \\
\hline Female & 20 & 9 \\
\hline$\leq 30$ years old & 17 & 8 \\
\hline$>30$ years old & 4 & 6 \\
\hline
\end{tabular}

their academic program had high standards that both faculty and students observed. Four people commented on the futility of cheating in a professional program such as physical therapy and occupational therapy, with Participant \#34 saying, "If the student wants to become a therapist, cheating won't help them in the field, so why not just learn the information?" Three others echoed similar thoughts, with Participant \#18 saying, "People will be putting their lives in our hands soon... I would be terrified if I needed rehab and I knew that my therapist had cheated through school." In summary, the participant comments support the findings of the Q-sort that students and faculty consider cheating behaviours to be opposite to their own, and many consider academic integrity to be essential to their life work.

\section{Discussion}

Our study revealed two distinct factors representing differing opinions on academic integrity. In some Q-studies, a two-factor solution might suggest opposing viewpoints in that the opinions expressed by those who define factor one are completely opposite to those who define factor two. If this was the case, it would be apparent in that individuals would have 'negative loadings' on the other factor (McKeown \& Thomas, 1988, p. 17). This is not the case with our study. The two factors reflect different perspectives on similarly-held beliefs. This is supported by the high number of consensus statements shared by both groups and by the statements that are unique to each group. Theiss-Morse, Fried, Sullivan and Dietz (1992) had similar findings in a study of patriotism, in which participants had a number of shared beliefs about being patriotic, and yet each group that defined a particular factor had its own unique perspective on patriotism. Our findings track with those of McCabe, Trevino and Butterfield (2001), whose review of a decade of research on academic integrity reported that an "encouraging aspect" of their findings is that many students and faculty share similar thoughts about academic dishonesty (p. 220).

The theoretical framework used to develop the Q-set of statements supports the nature of the unique viewpoints of the two factors in our study. Four defining statements for the Collective Integrity factor arose from the societal component of the framework, and contained elements of responsibility, respect, fairness, and honesty (see Table 1). This supports the interpretation that participants associated with this factor tend to view academic integrity from a group perspective, where the opinions of a larger whole influence how they behave. Personal Integrity is defined by two statements, both of which come from the personal component of the framework (see 
Table 1) related to responsibility. This gives credence to the analysis that those participants who defined this factor hold a more internal view of academic integrity and are minimally influenced by external factors.

The Personal Integrity and Collective Integrity perspectives appear to reflect certain elements of the libertarian-communitarian orientations of moral decision-making proposed by Bore, Munro, Kerridge and Powis (2005). Persons with a libertarian moral orientation place greater value on the well-being of the individual, and those with a communitarian orientation emphasise that of the group. Our study shows a similar orientation; however, it is important to note that those individuals who define the personal integrity factor are not necessarily self-centred in their decision-making, but they appear to make decisions based on internal values and beliefs related to what they think is right. In a different vein, individuals who define the collective integrity factor appear to make decisions that are influenced by what society believes is correct.

Of the demographic characteristics listed in Table 6, three appear to have some degree of association with particular opinions on academic integrity. These were: academic role (student or faculty), age and gender. More students, females, and younger individuals defined the Collective Integrity factor, which appears to have a group or society-oriented perspective. More faculty members, who were also older than most of the students, defined the Personal Integrity factor, which seems to have a more internally-driven outlook and may have an association with age or accumulation of life experiences.

Given that many students in this study tended to be younger and many faculty tended to be older, it is possible that the academic role and age factors are inter-related. These two factors, together or separately, appear to have an association with the Collective Integrity factor, and less of an association with the Personal Integrity factor. Of the twenty-one people associated with the Collective Integrity factor, only four were over the age of thirty, and one of these was the lone faculty member in this factor. This finding is similar to that of Hardigan (2004), who concluded that younger students have a more social outlook on academic integrity and see greater contextual relationships with behaviours such as cheating. Of the participants who defined the Personal Integrity factor, eight people were over the age of thirty and six were under thirty, resulting in no clear association of age with this factor. Three of the four faculty members in the study were associated with the Personal Integrity factor. Although too small to make a substantive conclusion, it would tend to indicate that faculty members may have a more internal sense of values and self-modulation.

Gender appears to have an association with the Collective Integrity factor more so than it does with the Personal Integrity factor. With females comprising the larger part of this study, it is no surprise that they are in both groups; however, twenty of the thirty-five female participants defined the Collective Integrity factor, whereas males, although fewer in number, were more evenly distributed between the two factors. Carol Gilligan's feminist theory may provide a useful theoretical lens through which to view this finding. Gilligan proposed that females develop in a relational way that focuses on connections among people. In contrast to what she described as a maleoriented ethic of justice linked to ideals of autonomy, independence, and selfsufficiency, Gilligan described a female ethic of care linked to realities of relationship and enjoining responsiveness, responsibility and carefulness (Gilligan, 1982). This theoretical perspective would lend credence to the interpretation that females, particularly younger ones, have opinions on academic integrity that are more socially oriented or collective in nature (Brown \& Gilligan, 1992).

Additional perspectives, particularly those that endorse cheating, did not emerge from this study. The literature, as well as some of the written comments in the demographic survey, suggests that this perspective does exist (Diekhoff et al., 1996; McCabe, 
1996; Turner \& Beemsterboer, 2003). Given that cheating behaviours are typically associated with a motivation to do less work, it is possible that those who would cheat may not volunteer for a research study such as this. Other potential barriers could include participant hesitancy to admit that certain cheating behaviours are more similar to their viewpoints than they would want the researchers to believe.

This $Q$ study has some limitations. Although a sample of thirty-eight is acceptable (Theiss-Morse, Fried, Sullivan, \& Dietz, 1992), perhaps a larger group of more diverse participants might have resulted in greater factors and different comments to aid in the interpretation of the factors. Because our initial analysis revealed a weak third factor, a larger number of participants might have established it as a factor for consideration. Even though the sample was reflective of student, faculty, age, and gender ratios for the academic program sampled, a larger group, particularly with more faculty members and males, may have allowed greater confidence in interpreting the demographic information. Although this study using $Q$ method produced interesting and useful insight into the opinions of health sciences students and faculty, it was unable to capture the statements that differentiate the deep differences we may have about the topic. Another interpretation might be that there are remarkable similarities among faculty and students when academic integrity is discussed. Future studies, both quantitative and qualitative, would allow a greater exploration of the opinions held by students and faculty and the influence of gender and age in academic integrity.

\section{Conclusion}

Although the participants in this study had shared opinions on academic integrity, they had differing, but not oppositional, viewpoints that emerged as two distinct factors. Those participants whose sorts defined the Collective Integrity factor view social responsibility as an integral part of their motivation in making academic decisions. Those participants in the Personal Integrity factor shared views representing a highly internal sense of values and self-modulation. Demographics of academic role, age, and gender have an association with the Collective Integrity factor more so than they do with the Personal Integrity factor. Exploration of these factors and demographics using various theoretical lenses proved quite enlightening.

The theoretical matrix of twenty potential viewpoints, consisting of four perspectives on the five behaviours that define academic integrity helped to inform our interpretation and naming of the factors. Four defining statements for the Collective Integrity factor arose from the societal component of the framework, and two defining statements for the Personal Integrity factor came from the personal component of the matrix. Additional theoretical interpretation of trends related to the demographic information of academic role, age, and gender provided additional insight. Gilligan's feminist theory of development suggests that females develop an ethic of care that focuses on connections among people, which tracks with our study, in which more young women tended to be associated with the Collective Integrity factor. The theory also proposes that males develop an ethic of justice linked to ideals of autonomy, independence, and self-sufficiency, which seems to bear out with an association, albeit weaker, between men and the Personal Integrity factor. Additional theoretical exploration could prove quite enlightening. Of particular interest might be the possible relationship of our two factors to the libertarian-communitarian dimension of moral decision-making.

The literature on academic integrity suggests that various forms of academic dishonesty are pervasive at institutions around the globe. This $Q$ method study provides insight into student and faculty perceptions on academic integrity. Perhaps the most important finding is that, although cheating likely occurs even in health sciences programs such as occupational and physical therapy, students and faculty appear to share a notable degree of common ground as it relates to their opinions on 
academic integrity. This provides an impetus for further dialogue and investigation of the matter, working toward the common goal of developing or continuing with established policies that promote academic integrity.

\section{Author biography}

Ken Randall, PT, MHR is Assistant Professor in the University of Oklahoma's Department of Rehabilitation Sciences in the College of Allied Health in the Midwestern United States. He is a physical therapist with a masters degree in human relations, and is in the dissertation phase of a PhD in educational psychology. He serves his university as a member of its Academic Appeals Board and Faculty Grievance Committee, and is chair of the Ethics Committee for his state professional association.

Denise Bender is an Associate Professor at University of Oklahoma Oklahoma's Department of Rehabilitation Sciences in the College of Allied Health. She is a licensed physical therapist with a board specialization in geriatrics and a degree in law. Professor Bender has both taught and published in the area of educational ethics.

Diane Montgomery is Professor of Educational Psychology at Oklahoma State University in the College of Education. Her areas of expertise and research include creativity, transpersonal psychology, Native American Indian education, gifted and talented education, and $Q$ methodology. She has held positions on several editorial boards and boards of directors of national professional organizations, including The Association for the Gifted, a division of the Council for Exceptional Children and American Council on Rural Special Education.

\section{References}

Barata, P. C. (2007). Abused women's perspectives on the criminal justice system's response to domestic violence. Psychology of Women Quarterly, 31, 202-215.

Bore, M., Munro, D., Kerridge, I., \& Powis, D. (2005). Selection of medical students according to their moral orientation. Medical Education, 39, 266-275.

Brimble, M., \& Stevenson-Clarke, P. (2005). Perceptions of the prevalence and seriousness of academic dishonesty in Australian universities. The Australian Educational Researcher, 32(3), 19-44.

Brown, S. R. (1993). A primer on Q-methodology. Operant Subjectivity, 16(3/4), 91138.

Brown, L. M., \& Gilligan, C. (1992). Meeting at the crossroads: Women's psychology and girl's development. New York: Ballantine.

Center for Academic Integrity. (2007, April 20). The Center for Academic Integrity: About us. Retrieved 20 April, 2007, from http://www.academicintegrity.org/ about us.asp.

Center for Academic Integrity (1999). The fundamental values of academic integrity: Honesty, trust, respect, fairness, responsibility. Durham, NC: Duke University. (ERIC Document Reproduction Service No. ED452778).

Cross, R. M. (2005). Exploring attitudes: The case for Q methodology. Health Education Research, 20(2), 206-213.

Davis, C. M. (1989). Patient practitioner interaction: An experiential manual for developing the art of health care. Thorofare, $\mathrm{NJ}$ : Slack.

Davis, M., Johnston, S. R., DiMicco, W., Findlay, M., \& Taylor, J. A. (1996). The case for a student honor code and beyond. Journal of Professional Nursing, 12(1), 24-30.

Diekhoff, G. M., LaBeff, E. E., Clark, R. E., Williams, L. E., Francis, B., \& Haines, V. J. (1996). College cheating: Ten years later. Research in Higher Education, 37(4), 487-502.

Falleur, D. (1990). An investigation of academic dishonesty in allied health: Incidence and definitions. Journal of Allied Health, 19(4), 313-324.

Gabbay, D. S. (1999). A medical student honor code. Emergency Medicine Clinics of North America, 17(2), 417-428. 
Gaberson, K. B. (1997). Academic dishonesty among nursing students. Nursing Forum, 32(3), 14-20.

Gilligan, C. (1982). In a different voice: Psychological theory and women's development. Cambridge: Harvard University Press.

Glick, S. M. (2001). Cheating in medical school. British Medical Journal, 322, 250-251.

Hall, T. L., \& Kuh, G. D. (1998). Honor among students: Academic integrity and honor codes at state-assisted universities. National Association of Student Personnel Administrators Journal, 36(1), 2-18.

Hardigan, P. C. (2004). First and third-year pharmacy students' attitudes toward cheating behaviors. American Journal of Pharmaceutical Education, 68(5), 1-5.

Joyce, D. (2007). Academic integrity and plagiarism: Australian perspectives. Computer Science Education, 17(3), 187-200.

Kilner, A. (2004) A national survey into the prevalence of plagiarism [On-line] Available www.freshminds.co.uk/FreshMinds_plagiarism_survey.pdf

Lin, C. S., \& Wen, L. M. (2007). Academic dishonesty in higher education: A nationwide study in Taiwan. Higher Education, 54, 85-97.

Lingen, M. W. (2006). Editorial: Tales of academic dishonesty and what do we do about it? Oral Surgery, Oral Medicine, Oral Pathology, Oral Radiology, and Endodontology, 102(4), 429-430.

Lupton, R. A., \& Chapman, K. J. (2002). Russian and American college student's attitudes, perceptions and tendencies towards cheating. Educational Research, 44(1), 17-27.

McCabe, D. L. (1996). What we know about cheating in college. Change, 28, 28-33.

McCabe, D. L., Trevino, L. K., \& Butterfield, K. D. (2001). Cheating in academic institutions: A decade of research. Ethics \& Behavior, 11(3), 219-232.

McCabe, D. L., Trevino, L. K., \& Butterfield, K. D. (2002). Honor codes and other contextual influences on academic integrity: A replication and extension to modified honor code settings. Research in Higher Education, 43(3), 357-378.

McKeown, B. \& Thomas, D. (1988). Q Methodology. Volume 66 Quantitative Applications in the Social Sciences Series. Newbury Park, CA: Sage.

Niels, G. J. (1996). Is the honor code a solution to the cheating epidemic? New York, NY: Esther A. and Joseph Klingenstein Center for Independent School Education. (ERIC Document Reproduction Service No. ED423191).

Rabi, S. M., Patton, L. R., Fjortoft, N., \& Zgarrick, D. P. (2006). Characteristics, prevalence, attitudes, and perceptions of academic dishonesty among pharmacy students. American Journal of Pharmaceutical Education, 70(4), 1-8.

Schmolck, P., \& Atkinson, J. (2002). PQMethod 2.11 Manual [on-line]. Available http:// www.qmethod.org/Tutorials/PQMethodManual.htm

Sharman, J. C., \& Wilshire, C. (2007). Fighting plagiarism in Australian Universities: Why bother? Australian Journal of Political Science, 42(3), 503-508.

Smith, N. W. (2001). Operant subjectivity: Objectivity of subjectivity. In N. W. Smith, Current systems in psychology: History, theory, research, and applications Belmont, CA: Wadsworth/Thomson Learning.

Stephenson, W. (1953). The study of behavior. Chicago: University of Chicago Press.

Szabo, A., \& Underwood, J. (2004). Cybercheats: Is information and communication technology fuelling academic dishonesty? Active Learning in Higher Education, 5 (2), 180-199

Theiss-Morse, E., Fried, A., Sullivan, J. L., \& Dietz, M. (1992). Mixing methods: A multistage strategy for studying patriotism and citizen participation. Political Analysis, 3, 89-121.

Turner, S. P. \& Beemsterboer, P. L. (2003). Enhancing academic integrity: Formulating effective honor codes. Journal of Dental Education, 67(10), 1122-1129).

Tyre, T. (2001). Their cheatin' hearts: High numbers for web-assisted plagiarism are disquieting, and so are the reasons, but remedies do exist. District Administration, $37(10), 32-35$. 